Lichenologist 25(1): 83-95 (1993)

\title{
DIFFERENTIAL HERBIVORE DAMAGE TO CALCICOLOUS LICHENS BY SNAILS
}

\author{
Lars FRÖBERG^, Anette BAUR $\ddagger$ and Bruno BAUR $\ddagger$
}

\begin{abstract}
A laboratory experiment was conducted to determine the damage caused by snail grazing to 35 calcicolous lichen species and cyanobacteria from the Baltic island of Öland, Sweden. Individuals of four species of land snails (Balea perversa, Chondrina clienta, Clausilia bidentata and Helicigona lapicida) were allowed to graze on identified lichen species growing on pieces of limestone. Snail grazing on thalli and ascocarps was classified into four categories ranging from no damage to completely eaten. In general, some lichen species were heavily grazed, whereas others were only slightly damaged or not injured. Aspicilia calcarea, Tephromela atra and Verrucaria nigrescens were preferred by all snail species except Chondrina clienta. In general, lichen thalli that were not immersed in the calcareous rock and cyanobacteria were preferred, whereas ascocarps were avoided by one of the snail species ( $C$. clienta). Immersed perithecia with a carbonized outer layer were avoided by all snail species except $C$. bidentata. Possibilities of chemical and mechanical defence properties in calcicolous lichens are discussed.
\end{abstract}

\section{Introduction}

The effects of herbivory on lichens and their subsequent regeneration have been briefly mentioned in Poelt (1969), Ozenda \& Clauzade (1970), Wunder (1974) and Wirth (1980). Among invertebrates, various species of terrestrial gastropods have been reported as lichen grazers (Schmid 1929; Plitt 1934; Frömming 1954; Coker 1967; Peake \& James 1967; Yom-Tov \& Galun 1971; James \& Henssen 1976; Gerson \& Seaward 1977; Lawrey 1980, 1983a, $b$; Seaward 1988). Lawrey $(1980,1983 a, b)$ showed that the preference for lichens by a slug depended on the chemical content of the thalli. However, in these investigations of lichen-herbivore relationships, estimation of the damage to individuals was not made.

One-hundred-and-eight calcicolous lichen species have been reported from the Great Alvar, a limestone grassland on the Baltic island of Öland, Sweden (Fröberg 1988, 1989). On a $1 \cdot 2$ ha limestone pavement in the Great Alvar, 17 species of terrestrial gastropods have been found, four of them being potential lichen feeders (Baur 1987). Experiments demonstrated that (1) these snail species grow and reproduce when kept on pieces of limestone covered with lichens and cyanobacteria, and (2) both intra- and interspecific competition for lichens occur among these snail species (Baur 1988; Baur 1990; Baur \& Baur 1990).

In this study, we have quantified the damage to various species of calcicolous lichens by snail grazing. Pieces of limestone covered with lichens were offered

\footnotetext{
^Department of Systematic Botany, University of Lund, Östra Vallgatan 18-20, S-223 61 Lund, Sweden. \$Zoological Institute, Basel University, Rheinsprung 9, CH-4051 Basel, Switzerland.
} 
to individuals of four species of rock-dwelling land snails (Balea perversa (L.), Chondrina clienta (Westerlund), Clausilia bidentata (Ström), and Helicigona lapicida (L.)) for a period of defined length, after which the damage to the lichens was examined as well as the snails' faeces. In particular, the following questions were addressed:

(1) Are endolithic and epilithic lichens differently grazed by individuals from different snail species?

(2) Are lichens with green photobionts or cyanobacteria preferred by any of the snail species?

(3) Are thalli or ascocarps preferentially grazed by the snails?

(4) Are apothecia or perithecia differentially grazed by the snails?

\section{Materials and Methods}

\section{Study area}

The lichens studied were collected in the limestone grassland Great Alvar in the southern part of the Baltic island of Öland, Sweden $\left(56^{\circ} 33^{\prime} \mathrm{N}, 16^{\circ} 36^{\prime} \mathrm{E}\right)$ on 12 September 1990 . Vegetation, climate and geomorphology of the Great Alvar have been described in detail by Rosén (1982). Samples of lichens were collected at three sites:

(1) Tornrör, Gärdby parish, on scattered rocks and a stone wall (made of flat pieces of limestone arranged in horizontal layers).

(2) $10 \mathrm{~km}$ E of Mörbylånga, on a limestone pavement $(50 \mathrm{~m} \times 40 \mathrm{~m})$.

(3) $1.4 \mathrm{~km}$ W of the southernmost tip of the marsh area Mökelmossen, on a stone wall on the southern side of the road connecting Resmo and Stenåsa.

\section{Lichens}

The lichen nomenclature follows Santesson (1984), except for Aspicilia contorta subsp. contorta, A. contorta subsp. hoffmanniana Ekman \& Fröberg ined., Bagliettoa baldensis (Massal.) Vězda, Clauzadea immersa (Hoffm.) Hafellner \& Bellem., Collema fuscovirens (With.) Laundon, Farnoldia jurana (Schaer.) Hertel, Gyalecta subclausa Anzi, Lecania rabenhorstii (Hepp) Arnold and Tephromela atra (Huds.) Hafellner. Lecanora dispersa II and Verrucaria glaucina correspond to L. dispersa type 2 and V. glaucina auct., non Ach. in Fröberg (1989).

\section{Snails}

Specimens of the land snails Balea perversa, Chondrina clienta, Clausilia bidentata and Helicigona lapicida were collected at the sites described above. Balea perversa (Fig. 1A) is characteristic of dry places among rocks and old stone walls, occurring occasionally on stems of trees. It is widespread in western Europe, and in Scandinavia it occurs mainly along the coast (Kerney \& Cameron 1979). Chondrina clienta (Fig. 1B) occurs in open limestone areas of central and south-eastern Europe and in three isolated areas of Sweden (Kerney \& Cameron 1979; Baur 1988). Clausilia bidentata is a widespread species in Europe, occurring among rocks and in woods and hedgebanks. Its slender conical shell is sinistral and in adults is $9-12 \mathrm{~mm}$ high (Kerney \& Cameron 1979). Helicigona lapicida is common in holes and crevices in rocky ground, and in old woodland and hedgerows in western and central Europe. Fully-grown snails have a flattened, sharply keeled shell measuring 12-20 mm in diameter (Kerney \& Cameron 1979). All species are particularly well adapted to rocky habitats; they are very resistant to drought with activity confined to periods of high air humidity, and their specialized radulae enable them to graze epi- and endolithic lichens from rock-faces (Schmid 1929; Gittenberger 1973; Breure \& Gittenberger 1982). Snail grazing on endolithic lichens contributes to the erosion of rocky habitats (Danin 1986; Shachak et al. 1987; Jones \& Shachak 1990).

\section{Experimental methods}

To investigate damage due to grazing, individuals of the four snail species were kept on pieces of limestone covered with 1-11 lichen species for periods of 10-25 days (Table 1). For this purpose the 

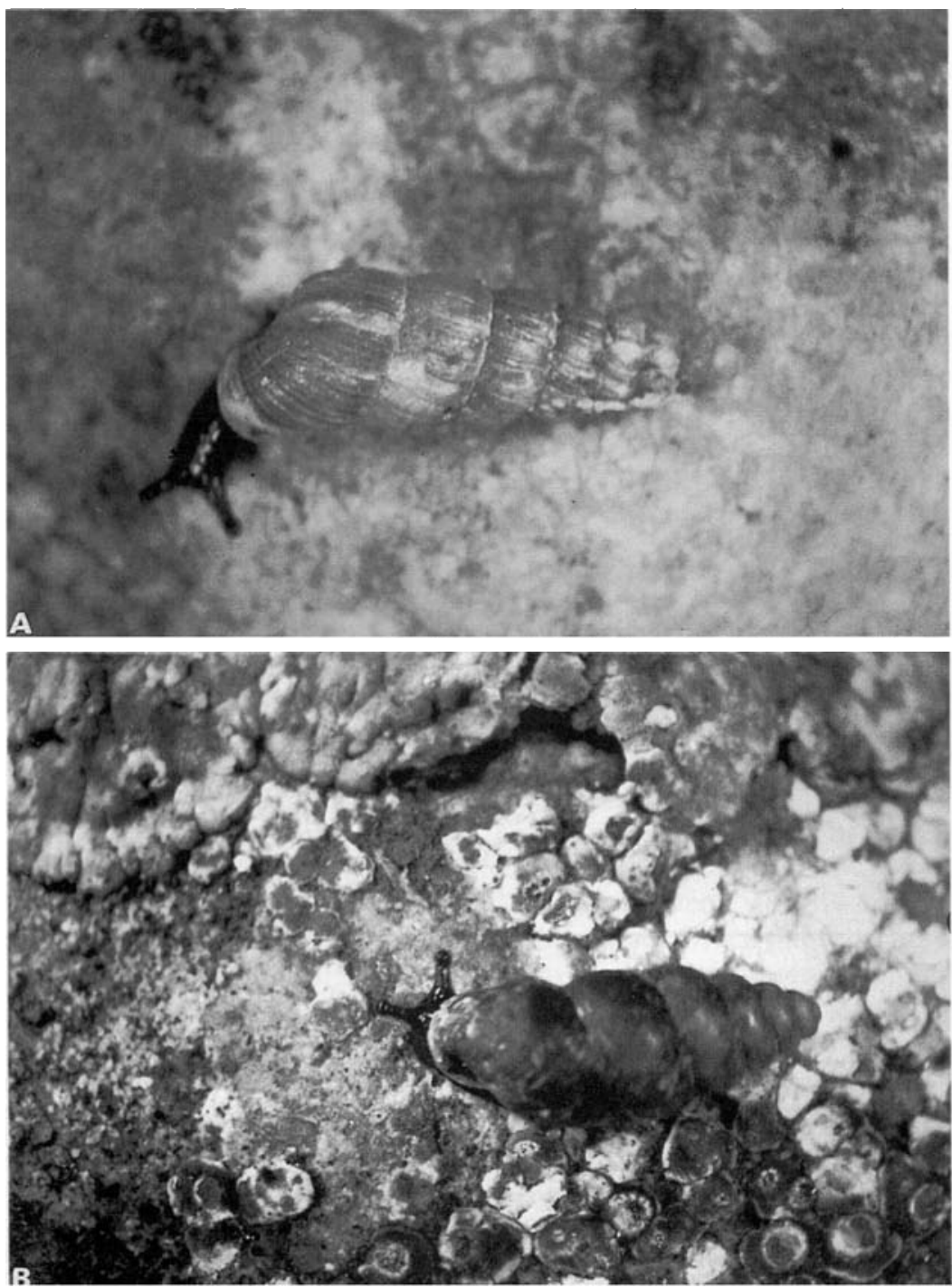

FIG. 1. Adult snails. A, Balea perversa (shell height $9.8 \mathrm{~mm}$ ); B, Chondrina clienta (shell height $6.1 \mathrm{~mm}$ )

lichen samples were placed in transparent plastic containers lined with paper towelling. Two to 50 adult snails were put on the pieces of limestone (Table 1).

All snails belonged to the same species within each container. To stimulate periodic snail activity, the containers were moistened and kept wet for $12 \mathrm{~h}$ and subsequently allowed to dry out for $36 \mathrm{~h}$. For details of snail maintenance see Baur \& Baur (1990). To compare grazed and ungrazed lichens on the same piece of stone at the end of the experiment, approximately half of the area with lichen vegetation was covered with opaque tape.

Lichen species were identified microscopically and the damage caused by snail grazing was carefully examined using a dissecting microscope. The level of grazing was classified as follows: 
TABLE 1. Number of snails and days they were allowed to graze on a piece of limestone; each line represents one trial

\begin{tabular}{|c|c|c|c|c|}
\hline Snail species & $\begin{array}{l}\text { No. of snail } \\
\text { individuals }\end{array}$ & $\begin{array}{l}\text { No. of grazing } \\
\text { days per snail }\end{array}$ & $\begin{array}{c}\text { Size of } \\
\text { limestone } \\
\left(\mathrm{mm}^{2}\right)\end{array}$ & $\begin{array}{c}\text { No. of lichen } \\
\text { species } \\
\text { present }\end{array}$ \\
\hline \multirow[t]{3}{*}{ Balea perversa } & 10 & 10 & 800 & 2 \\
\hline & 5 & 10 & 150 & 2 \\
\hline & 10 & 25 & 800 & 4 \\
\hline \multirow[t]{15}{*}{ Chondrina clienta } & 10 & 10 & 600 & 5 \\
\hline & 10 & 10 & 900 & 6 \\
\hline & 7 & 10 & 450 & 2 \\
\hline & 5 & 10 & 350 & 3 \\
\hline & 10 & 10 & 550 & 2 \\
\hline & 5 & 10 & 350 & 1 \\
\hline & 3 & 10 & 60 & 1 \\
\hline & 3 & 10 & 50 & 2 \\
\hline & 7 & 10 & 450 & 2 \\
\hline & 10 & 10 & 1100 & 11 \\
\hline & 10 & 10 & 1400 & 6 \\
\hline & 40 & 10 & 1700 & 6 \\
\hline & 10 & 10 & 1700 & 3 \\
\hline & 50 & 10 & 3500 & 7 \\
\hline & 10 & 6 & 800 & 2 \\
\hline Clausilia bidentata & 2 & 6 & 200 & 4 \\
\hline \multirow[t]{5}{*}{ Helicigona lapicida } & 4 & 6 & 2000 & 8 \\
\hline & 7 & 6 & 3500 & 7 \\
\hline & 7 & 6 & 5000 & 5 \\
\hline & 7 & 6 & 3200 & 4 \\
\hline & 2 & 6 & 800 & 3 \\
\hline
\end{tabular}

lichen thalli without photobiont layer exposed $(0=$ no grazing $)$; less than half of lichen thalli with photobiont layer exposed ( + , low level of grazing); more than half of lichen thalli with photobiont layer exposed $(++$, moderate level of grazing); lichens with most of the thallus including the photobiont layer removed $(+++$, high level of grazing). If earlier grazing damage had occurred, the damage during the experiment could be determined by comparison with that in the area covered with tape. A four-grade scale was also used to judge ascocarp damage and damage to free-living cyanobacteria. Two slides with faeces were made for each trial to search microscopically for any identifiable remains of lichens and cyanobacteria.

Interspecific comparisons of snail grazing were based on damage to the thalli, except in Caloplaca holocarpa and C. velana. In the latter species, the ascocarps dominate the surface of the individuals and thus damage to them was used instead. Preferences for type of thallus (endolithic/epilithic), type of alga (green photobiont/cyanobacteria), part of lichen (thallus/ascocarp) and type of ascocarp (apothecium/perithecium) were tested for each snail species with the exception of type of alga in $H$. lapicida and C. bidentata and type of thallus in C. bidentat $a$ where the sample sizes were too low. In another experiment, a mixed-species group (ten B. perversa and ten C. clienta) were allowed to graze on the lichens on a piece of limestone. However, these data were exclusively used for illustrations (Fig. 2C, D) and not in statistical analyses.

We defined grazing pressure as the total number of snail days a lichen was exposed to grazing (number of individuals multiplied by number of grazing days per snail; Table 1). Since grazing pressure varied among lichen samples (Table 1), we calculated the relative grazing defined as the level of grazing (see above) divided by the grazing pressure and multiplied by 100 (i.e. relative grazing $=$ [level of grazing/grazing pressure] $\times 100$ ). Relative grazing was used in all comparisons of grazing among the lichens. All statistical analyses were performed using the SAS program package (SAS Institute 1990). 


\section{Results}

\section{Grazing damage}

In most cases, grazing damage by the snails could be easily observed, since the green photobiont layer, which was more or less exposed when grazed, contrasted against the normal thallus colour (Fig. 2C-E). In some cases, the whole thallus was removed (Fig. 2E, F). When the ascocarps were grazed, the hypothecium or lower part of the hymenium was exposed, exhibiting a lighter colour (Fig. 2E). Cyanobacteria were also grazed, as indicated by the lighter colour of the exposed underlying rock surface (Fig. $2 B$ ). In a few cases, cyanobacteria on Aspicilia calcarea were grazed without the photobiont layer of the underlying lichen being exposed (Fig. 2E).

Table 2 summarizes the damage to various species of lichens due to snail grazing. The damage varied considerably, depending both on the lichen and the snail species. Several lichen species differed in damage to the thallus and ascocarp, even within the same individual.

\section{Faecal remains}

Faecal remains and mucous trails from the snails were frequently observed. Faeces were either blackish (containing mainly cyanobacteria), greenish (containing mainly green photobionts from lichens), or whitish (containing mainly limestone granules) (Fig. 2A). In microscopic preparations of the faeces, cyanobacteria were frequently found in large amounts. Free-living cyanobacteria belonged to the genera Chroococcus, Gloeocapsa and Gloeothece of the family Chroococcaceae (identified by direct microscopic observation of areas previously covered by tape). Cells seemed intact, although the surrounding mucilaginous sheaths were reduced to some extent. In one case, a few Nostoc cells of Collema fuscovirens were also observed. Green photobionts of the lichens were usually found in small amounts, and almost always damaged. Furthermore, algal cells belonging to the genus Trentepohlia were recorded in one case, but no fungal hyphae were observed in the faeces. In a few cases, lichen remains were identified, including a fragment of an apothecium of Rinodina immersa consisting of paraphyses and asci with spores. A few Caloplaca spores, a spore of Polyblastia deminuta and a piece of a hymenium, possibly belonging to a species of Aspicilia, were also recorded.

\section{Selective grazing by different snail species}

The damage caused by a particular snail species varied among lichen species and, most interestingly, also to some extent between thallus and ascocarp of the same lichen, indicating selective grazing (Table 2). Both $A$. calcarea and Verrucaria nigrescens were intensively grazed by Balea perversa, Helicigona lapicida and Clausilia bidentata, and Tephromela atra by B. perversa (cf. Fig $2 \mathrm{C}$ \& E), while Chondrina clienta did not feed on these three lichen species (Table 2).

Table 3 presents the preferences of the four snail species to epilithic/ endolithic lichens, green photobionts/cyanobacteria, thalli/ascocarps and apothecia/perithecia. Balea perversa showed no overall preference for endolithic or epilithic lichens, type of alga, or for part of lichen. However, 

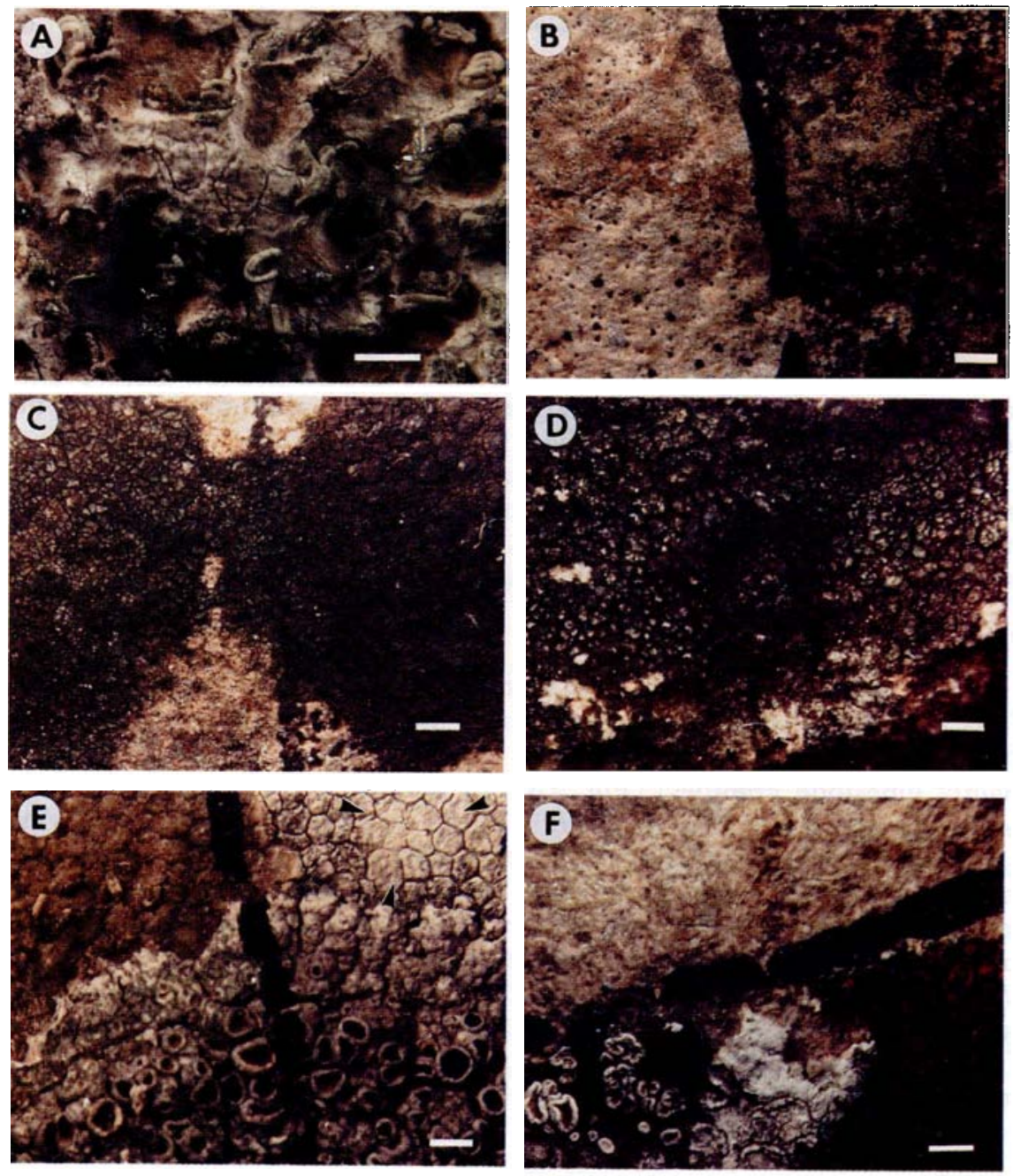

Fig. 2. A, Faecal remains and mucous trails of Balea perversa. The faeces are either white (containing mainly limestone granules), green (containing mainly green photobionts) or black (containing mainly cyanobacteria). B, Cyanobacteria grazed by Chondrina clienta (left half). The black line separates the grazed and ungrazed areas. The underlying lichen Clauzadea immersa is exposed due to grazing. C, Verrucaria nigrescens grazed by $B$. perversa and $C$. clienta (left half). The photobiont layer can be seen as green patches where grazing has occurred. D, Verrucaria glaucina grazed by $B$. perversa and $C$. clienta (right half). The photobiont layer can be seen as green patches where grazing has occurred. The perithecia that are immersed in the photobiont layer are visible as minute dots within green patches. E, Tephromela atra (lower part) and Aspicilia calcarea (upper part) grazed by $B$. perversa (left half). The thallus edge of $T$. atra has been more grazed than the central parts, and the apothecia are also slightly grazed, exhibiting a lighter colour. Aspicilia calcarea has completely vanished due to the grazing. Note the cyanobacteria on the upper right part of the illustration, growing in thread-like colonies on $A$. calcarea. They have been grazed prior to the experimental grazing, probably by $C$. clienta, without the snails penetrating the lichen beneath (grazed parts indicated by arrows). F, Lecanora dispersa, Aspicilia calcarea and Caloplaca velana grazed by Helicigona lapicida (upper half). The epilithic lichen cover has completely vanished due to snail grazing. Scale $=1 \mathrm{~mm}$. 
individuals of $B$. perversa preferred to graze on apothecia. Chondrina clienta grazed more on epilithic than on endolithic lichens and preferred cyanobacteria to lichens with a green photobiont. Furthermore, $C$. clienta preferred to graze on lichen thalli rather than on ascocarps and on apothecia rather than perithecia. Individuals of $H$. lapicida showed no preferential grazing with respect to type or part of thallus, but preferred to graze on apothecia. Clausilia bidentata showed no preferential grazing with respect to part of lichen and type of ascocarp.

\section{Discussion}

Several differences in grazing damage were found among the lichen species in this study. In general, Aspicilia species, Caloplaca species and cyanobacteria were heavily grazed, whereas Bagliettoa baldensis, Clauzadea immersa and Verrucaria calciseda as well as other endolithic species were not or only slightly grazed. Snail grazing may affect the life-history and population dynamics of lichen species, but so far no quantitative information is available on the damage to lichen individuals, or on what happens to lichens after grazing has occurred. If only the upper part of the thallus has been grazed, regeneration of the lichen individual may occur. If the whole thallus has disappeared, either the original lichen individual may recolonize the grazed area, or colonization by other lichens occurs. It has often been argued that regenerated lichen individuals can exhibit new characters. For example, Wunder (1974) claims that Caloplaca variabilis may even transform from an epilithic to endolithic appearance when regenerated from severe grazing damage. However, such deductions must be based on careful observations of the different stages during regeneration. Genetic variation within $C$. variabilis is more likely the most important reason for the occurrence of both epilithic and endolithic morphotypes (cf. Fröberg 1989).

The differential grazing damage observed indicates selective snail grazing. The occurrence of species-specific grazing preferences suggests different adaptations of snails to a particular lichen species or, alternatively, differential ingestive conditioning (cf. Wood 1968; Hall et al. 1982). The lack of hyphae in the faeces as well as the occurrence of partially digested green photobionts suggest that the grazed lichens provide the snail with nutrients. Furthermore, avoidance of grazing can, in many cases, be explained by the chemical content of the lichen. Lawrey $(1980,1983 a)$ showed that Aspicilia gibbosa and $A$. cinerea, both containing the fatty acid aspicilin, were heavily grazed by the slug Pallifera varia. In contrast, lichens containing stictic or protocetraric acid were avoided. Aspicilia calcarea, which also contains aspicilin, was heavily grazed by three species in this study, but avoided by $C$. clienta.

On coastal cliffs on the island of Bornholm, Denmark, mites and Collembola were associated with Tephromela atra, which contains atranorin and $\alpha$ collatolic acid (Gelstrup \& Søchting 1984; Søchting \& Gelstrup 1985). Other lichen species containing atranorin were eaten by the slug $P$. varia (Lawrey 1980 , 1983a). Similarly, in the present study $B$. perversa fed on $T$. atra, but $C$. clienta avoided this lichen. More detailed experiments are needed to evaluate the underlying mechanisms for these snails' feeding preferences. Tephromela atra 
TABLE 2. Summary of damage to various species of calcicolous lichens, cyanobacteria and one green alga, due to snail grazing by four species of land snails

\begin{tabular}{|c|c|c|c|c|c|}
\hline \multirow[b]{2}{*}{ Species } & \multirow{2}{*}{$\begin{array}{c}\text { Snail } \\
\text { species }+\end{array}$} & \multicolumn{4}{|c|}{ Level of grazing ${ }^{\star}$} \\
\hline & & Thallus & $N \S$ & Ascocarp & $\mathbf{N}$ \\
\hline \multirow[t]{4}{*}{ Aspicilia calcarea } & $B p$ & +++ & 1 & +++ & 1 \\
\hline & $C c$ & $(+)$ & 5 & $(+)$ & 5 \\
\hline & $C b$ & +++ & 1 & - & \\
\hline & $H l$ & +++ & 3 & +++ & 2 \\
\hline A. contorta agg. & $H l$ & +++ & 1 & +++ & 1 \\
\hline A. contorta subsp. contorta & $C c$ & + & 1 & ++ & 1 \\
\hline \multirow[t]{2}{*}{ A. contorta subsp. hoffmanniana } & $C c$ & ++ & 2 & ++ & 2 \\
\hline & $H l$ & +++ & 1 & +++ & 1 \\
\hline Bagliettoa cf. baldensis & $C c$ & 0 & 2 & 0 & 2 \\
\hline Buellia epipolia & $C c$ & + & 1 & 0 & 1 \\
\hline \multirow{2}{*}{ Caloplaca citrina } & $C c$ & ++ & 1 & + & 1 \\
\hline & $H l$ & +++ & 3 & +++ & 1 \\
\hline C. holocarpa & $C c$ & 0 & 1 & ++ & 1 \\
\hline C. saxicola & $H l$ & +++ & 1 & +++ & 1 \\
\hline \multirow[t]{2}{*}{ C. variabilis } & $B p$ & +++ & 1 & +++ & 1 \\
\hline & $C c$ & ++ & 1 & 0 & 1 \\
\hline \multirow[t]{2}{*}{ C. velana } & $C c$ & ++ & 2 & + & 2 \\
\hline & $H l$ & $++t$ & 1 & +++ & 1 \\
\hline \multirow[t]{2}{*}{ Catillaria lenticularis } & $C c$ & + & 1 & 0 & 1 \\
\hline & $H l$ & +++ & 1 & +++ & 1 \\
\hline Glauzadea immersa & $C c$ & 0 & 8 & $(+)$ & 8 \\
\hline \multirow{2}{*}{ Collema fuscovirens } & $B p$ & + & 1 & - & \\
\hline & $C c$ & 0 & 1 & - & \\
\hline Cyanobacteria & $C c$ & ++ & 7 & - & \\
\hline Farnoldia jurana & $C c$ & + & 1 & - & \\
\hline Gyalecta subclausa & $C c$ & 0 & 1 & 0 & 1 \\
\hline Lecania rabenhorstii & $C c$ & ++ & 1 & ++ & 1 \\
\hline \multirow[t]{2}{*}{ Lecanora albescens } & $C c$ & + & 1 & 0 & 1 \\
\hline & $\mathrm{Hl}$ & +++ & 2 & +++ & 2 \\
\hline L. crenulata & $C c$ & 0 & 1 & 0 & 1 \\
\hline L. dispersa s. lat. & $H l$ & +++ & 1 & +++ & 1 \\
\hline L. dispersa type II & $C c$ & 0 & 1 & + & 1 \\
\hline Phaeophyscia nigricans & $H l$ & +++ & 2 & - & \\
\hline Physcia adscendens & $C c$ & 0 & 1 & - & \\
\hline Protoblastenia rupestris & $C b$ & +++ & 1 & +++ & 1 \\
\hline Rinodina bischoffii & $C c$ & 0 & 1 & 0 & 1 \\
\hline \multirow[t]{2}{*}{ R. immersa } & $B p$ & + & 1 & ++ & 1 \\
\hline & $\mathrm{Hl}$ & ++ & 3 & ++ & 3 \\
\hline Staurothele caesia & $C c$ & 0 & 1 & 0 & 1 \\
\hline S. cf. guestphalica & $B p$ & + & 1 & 0 & 1 \\
\hline \multirow[t]{2}{*}{ Tephromela atra } & $B p$ & ++ & 1 & ++ & 1 \\
\hline & $C c$ & 0 & 1 & 0 & 1 \\
\hline \multirow[t]{2}{*}{ Thelidium decipiens } & $C c$ & + & 4 & 0 & 4 \\
\hline & $H l$ & ++ & 2 & ++ & 2 \\
\hline Trentepohlia sp. & $C c$ & ++ & 1 & - & \\
\hline \multirow[t]{2}{*}{ Verrucaria calciseda } & $C c$ & 0 & 3 & 0 & 3 \\
\hline & $H l$ & + & 2 & + & 2 \\
\hline V. caerulea & $C c$ & + & 2 & + & 2 \\
\hline$V$. dufourii & $C c$ & + & 2 & 0 & 2 \\
\hline$V$. glaucina & $C b$ & ++ & 1 & ++ & 1 \\
\hline
\end{tabular}


TABLE 2. Continued

\begin{tabular}{|c|c|c|c|c|c|}
\hline \multirow[b]{2}{*}{ Species } & \multirow{2}{*}{$\begin{array}{c}\text { Snail } \\
\text { species }\end{array}$} & \multicolumn{4}{|c|}{ Level of grazing } \\
\hline & & Thallus & N\$ & Ascocarp & $\mathbf{N}$ \\
\hline$V$. macrostoma & $H l$ & ++ & 1 & ++ & 1 \\
\hline V.muralis & $B p$ & + & 1 & 0 & 1 \\
\hline \multirow[t]{4}{*}{$V$. nigrescens } & $B p$ & ++ & 1 & ++ & 1 \\
\hline & $C c$ & + & 3 & 0 & 1 \\
\hline & $C b$ & ++ & 1 & ++ & 1 \\
\hline & $\mathrm{Hl}$ & $+t$ & 3 & ++ & 3 \\
\hline
\end{tabular}

^Four levels of grazing were distinguished: no grazing $(0)$, low $(+)$, moderate $(++)$, and high $(+++)$ grazing.

$\ddagger B p=$ Balea perversa, $C c=$ Chondrina clienta, $C b=$ Clausilia bidentata, $H l=$ Helicigona lapicida. $\S \mathrm{N}=$ Number of observations.

and $A$. calcarea are most abundant on stone walls, where $B$. perversa occurs at high densities. Most interestingly, the grazing damage by $B$. pervers $a$ on $T$. atra was more severe at the edge of the thallus (Fig. 2E), which presumably is the youngest part of the lichen. The arguments by Lawrey (1984: 254) that the protection against grazers by secondary metabolites is most important in young, metabolically active parts of the thalli stresses the fact in our study that none of the secondary metabolites in $T$. atra acts as an antiherbivore agent against $B$. perversa.

Verrucaria nigrescens does not contain any secondary metabolites. Consequently, other factors might be responsible for the low grazing rate of $C$. clienta. Perhaps the carbonized tissue of $V$. nigrescens is less attractive to snails than non-carbonized tissues of other lichens. All Caloplaca species were intensively grazed by the snails. Thus, their content of parietin and related substances does not seem to adversely affect snail grazing (cf. Fröberg 1989).

Collema fuscovirens, the only lichen in this study with cyanobacteria as photobiont, was not grazed by $C$. clienta and hardly by $B$. perversa. This contrasts with the finding that $C$. clienta readily fed on free-living cyanobacteria. Gerson (1973) reported the resistance of gelatinous lichens to invertebrate feeders. This could also be a reason for the avoidance by the snails in the present investigation. Avoidance of lichens with cyanobacteria as photobiont by Clausilia species, was also reported in the case of Sticta canariensis-dufourii by James \& Henssen (1976).

The grazing damage caused by the four snail species was compared with some properties of the lichens (Table 3). The damage to epilithic lichens by Chondrina clienta was significantly larger than that to endolithic ones. The high proportion of endolithic species on calcareous rocks in the area studied may in part be induced by invertebrate herbivores. However, neither the grazing of Balea perversa nor Helicigona lapicida showed any significant damage as to type of thallus.

Chondrina clienta also showed a significant preference for cyanobacteria (mainly free-living), compared with green photobionts in lichens (Table 3). 


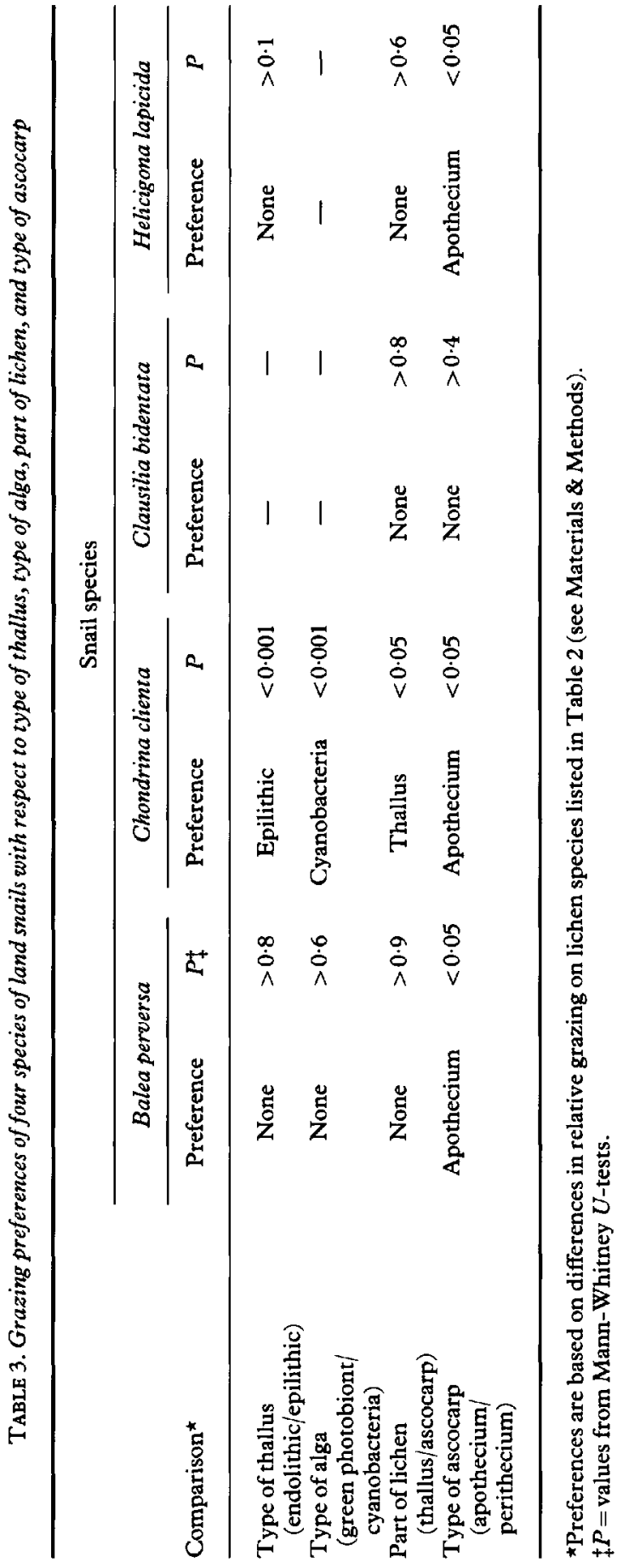


Although the cyanobacterial cells in the faeces were intact, their sheaths, presumably containing polysaccharides (Mehta \& Vaidya 1978), were probably consumed. Furthermore, free-living cyanobacteria leak both polysaccharides and combined nitrogen (Mehta \& Vaidya 1978). For example, Anabaena sp. was reported to secrete polypeptides and shorter peptides, with a high proportion of serine, and polysaccharides, mostly consisting of galactose and glucose (Paerl 1982). In this way the snails can benefit from the cyanobacteria without the energy-consuming breakdown of their cell walls. The cover of cyanobacteria on limestone pavements has almost completely vanished in the vicinity of certain crevices inhabited by individuals of $C$. clienta. The snails graze on the rock surface under conditions of high air humidity, leaving a conspicuous light zone on both sides of the crevice, which is dominated by Clauzadea immersa. An illustration of these crevices is given in Fröberg (1989: 9), where the light zone was wrongly inferred to be caused by weathering processes. No significant preference for type of alga was found in the grazing damage caused by $B$. perversa.

When comparing grazing damage to different parts of the same lichen, the thallus was more grazed than the ascocarps by $C$. clienta (Table 3). Lawrey (1984: 254) argued that protection against grazing is expected to be larger in the reproductive tissue than in vegetative tissue. It is possible that some of the lichen species contain substances in the hymenium that prevent grazing to some extent. The other three snail species showed no preference for different parts of the lichen.

Finally, the grazing damage to the apothecia was significantly higher than to the perithecia in the case of $B$. perversa, $C$. clienta and $H$. lapicida (Table 3 ). This is most probably due to the fact that perithecia in most of the lichen species studied are immersed in the substratum and thus protected. However, the carbonized excipulum surrounding the generative tissue in almost all species with perithecia could also play an important role for protection against grazers. The apothecia of Clauzadea immersa, which are immersed and have a carbonized excipulum, were almost completely avoided by the snails. Further investigations are needed to understand the complex interactions between lichens and their herbivores in the area studied.

We are grateful to Prof. V. Ahmadjian for comments on the manuscript. We also thank the staff at the Ecological Research Station of Uppsala University on Öland for their hospitality. Financial support has been provided by Lunds Botaniska Förening (grant to L. Fröberg), and the Swiss National Science Foundation (grant No. 31-26258.89 to B. Baur).

\section{REFERENCES}

Baur, A. (1990) Intra- and interspecific influences on age at first reproduction and fecundity in the land snail Balea perversa. Oikos 57: 333-337.

Baur, B. (1987) Richness of land snail species under isolated stones in a karst area on Öland, Sweden. Basteria 51: 129-133.

Baur, B. (1988) Microgeographical variation in shell size of the land snail Chondrina clienta. Biological Yournal of Linnean Society 35: 247-259.

Baur, B. \& Baur, A. (1990) Experimental evidence for intra- and interspecific competition in two species of rock-dwelling land snails. fournal of Animal Ecology 59: 301-315.

Breure, A. S. H. \& Gittenberger, E. (1982) The rock-scraping radula, a striking case of convergence (Mollusca). Netherlands fournal of Zoology 32: 307-312. 
Coker, P. D. (1967) Damage to lichens by gastropods. Lichenologist 3: 428-429.

Danin, A. (1986) Patterns of corrosion and abrasion induced by mediterranean land snails on limestone rocks. Malacological Review 19: 91-98.

Fröberg, L. (1988) Calcicolous lichens and their ecological preferences on the Great Alvar of Öland. Acta phytogeographica suecica 76: 47-52.

Fröberg, L. (1989) The calcicolous lichens on the Great Alvar of Oland, Sweden. Ph.D. Thesis. University of Lund.

Frömming, E. (1954) Biologie der mitteleuropäischen Landgastropoden. Berlin: Duncker and Humblot.

Gelstrup, P. \& Søchting, U. (1984) Oribatid mites (Acarina) dominant in some lichen and moss species of maritime rocks on Bornholm in the Baltic. Acarology 1: 528-532.

Gerson, U. (1973) Lichen-arthropod associations. Lichenologist 5: 434-443.

Gerson, U. \& Seaward, M. R. D. (1977) Lichen-invertebrate associations. In Lichen Ecology (M. R. D. Seaward, ed.): 69-119. London: Academic Press.

Gittenberger, E. (1973) Beiträge zur Kenntnis der Pupillacea III. Chondrininae. Zoologische Verhandelingen Leiden 127: 1-267.

Hall, S. J., Todd, C. D. \& Gordon, A. D. (1982) The influence of ingestive conditioning on the prey species selection in Aeolidia papillosa (Mollusca: Nudibranchia). Fournal of Animal Ecology 51: 907-921.

James, P. W. \& Henssen, A. (1976) The morphological and taxonomic significance of cephalodia. In Lichenology: Progress and Problems (D. H. Brown, D. L. Hawskworth \& R. H. Bailey, eds): 27-77. London: Academic Press.

Jones, C. G. \& Shachak, M. (1990) Fertilization of the desert soil by rock-eating snails. Nature 346: 839-841.

Kerney, M. P. \& Cameron, R. A. D. (1979) A Field Guide to the Land Snails of Britain and North-west Europe. London: Collins.

Lawrey, J. D. (1980) Correlations between lichen secondary chemistry and grazing activity by Pallifera varia. Bryologist 83: 328-334.

Lawrey, J. D. (1983a). Lichen herbivore preference: a test of two hypotheses. American fournal of Botany 70: 1188-1194.

Lawrey, J. D. (1983b) Vulpinic and pinastric acids as lichen antiherbivore compounds: contrary evidence. Bryologist 86: 365-369.

Lawrey, J. D. (1984) Biology of lichenized fungi. New York: Praeger.

Mehta, V. B. \& Vaidya, B. S. (1978) Cellular and extracellular polysaccharides of the blue-green alga, Nostoc. Fournal of Experimental Botany 29: 1423-1430.

Ozenda, P. \& Clauzade, G. (1970) Les lichens, étude biologique et flore illustrée. Paris: Masson.

Paerl, H. W. (1982) Interactions with bacteria. In The biology of cyanobacteria (N. G. Carr \& B. A. Whitton, eds): 441-461. Berkeley \& Los Angeles: University of California Press.

Peake, J. F. \& James, P. W. (1967) Lichens and Mollusca. Lichenologist 3: 425-428.

Plitt, C. C. (1934) A lichen-eating snail. Bryologist 37: 102-104.

Poelt, J. (1969) Bestimmungsschlüssel europäischer Flechten. Lehre: J. Cramer.

Rosén, E. (1982) Vegetation development and sheep grazing in limestone grasslands of south Öland, Sweden. Acta phytogeographica suecica 72: 1-108.

Santesson, R. (1984) The lichens of Sweden and Norway. Stockholm: Swedish Museum of Natural History.

SAS Institute (1990) SAS User's Guide: Statistics, 1990 edition. North Carolina: Cary.

Schmid, G. (1929) Endolithische Kalkflechten und Schneckenfrass. Biologisches Zentralblatt 49: 28-35.

Seaward, M. R. D. (1988) Contribution of lichens to ecosystems. In Handbook of Lichenology, Vol. II (M. Galun, ed.): 107-129. Boca Raton: CRC Press.

Shachak, M., Jones, C. G. \& Granot, Y. (1987) Herbivory in rocks and the weathering of a desert. Science 236: 1098-1099.

Søchting, U. \& Gelstrup, P. (1985) Lichen communities and the associated fauna on a rocky seashore on Bornholm in the Baltic. Holarctic Ecology 8: 66-75.

Wirth, V. (1980) Flechtenflora. Stuttgart: Eugen Ulmer.

Wood, L. (1968) Physiological and ecological aspects of prey selection by the marine gastropod Urosalpinx cinerea (Prosobranchia: Muricidae). Malacologia 6: 267-320. 
Wunder, H. (1974) Schwarzfrüchtige Saxicole-Sippen der Gattung Caloplaca (Lichenes, Teloschistaceae) in Mitteleuropa, dem Mittelmeergebiet und Vorderasien. Bibliotheca Lichenologica 3: 1-186.

Yom-Tov, Y.\& Galun, M. (1971) Note on feeding habits of the desert snail Sphincterochila boissieri Carpentier and Trochoidea (Xerocrassa) seetzeni Charpentier. Veliger 14: 86-88.

Accepted for publication 26 March 1992 
Downloaded from https:/www.cambridge.org/core. University of Basel Library, on 30 May 2017 at 12:57:03, subject to the Cambridge Core terms of use, available at https:/www.cambridge.org/core/terms. https://doi.org/10.1006/lich.1993.1015 